\title{
Engineering Design and Context: Moving Toward Ecosociotechnical Systems
}

\author{
Steven A Moore* \\ The University of Texas at Austin, USA
}

Submission: October 01, 2018; Published: October 15, 2018

*Corresponding author: Steven A Moore, The University of Texas at Austin, USA; Tel: 5129341013; Email: samoore@austin.utexas.edu

\section{Opinion}

In the modern view generally accepted by non-scientists, science is understood to be the process, or method of accumulating abstract truths. From this perspective, truths are composed of multiple facts that may be universally applied. For example, the properties of lead are said to be the same in Zimbabwe as they are in Canada. Once scientists establish such truths, they are handedover to practical designers (e.g., engineers, architects, medical practitioners ....) to solve problems in the messy conditions of the world. Surprisingly, however, this modern dualistic view of the world is less a departure from the mystical past than was claimed by advocates of modernity. Rather, modern philosophical dualisms simply reproduce the ancient separation of mind and matter, or God and man. Such popular understanding of science suggests that we have not yet finished the Modern project.

One problem with these popular modern dualisms is that the progenitors of modern science, Francis Bacon (1521-1626) for example, thought differently. In lieu of universal truths established deductively, he understood science to be the accumulation of empirical or inductive data that established only probabilities that any hypothesis would prove useful in a particular context. The more empirical data collected in support of a hypothesis produced greater social certainty that it could be successfully applied. There were, however, conditions. Modern science relies on the ceteris paribus clause which states-all things being equal we can expect $\mathrm{x}, \mathrm{y}$ or $\mathrm{z}$ to happen when the variables $\mathrm{a}, \mathrm{b}$ and $\mathrm{c}$ come into contact. Notice that requiring all things to remain the same is to hold that certainty requires constant social and ecological conditions, not just physical ones.

In our current situation, we recognize that both social and ecological contexts in the world are changing at a rate never before anticipated. They are not now constant, nor were they ever. Not only is the climate changing in response to anthropocentric activity, but those dynamic climatic conditions contribute to human migration and cultural adaptation at a scale unimaginable only a few decades ago. For example, the recent droughts in Africa have catalyzed not only mass migrations but also armed conflicts that make conventional approaches to water sequestration and irrigation irrelevant. It is because of these causal links that I will argue that modern science may not be wrong, but it is very incomplete. I mean by this that it is no longer adequate for science to limit the boundaries of what we study to physical phenomena. Rather, it has become necessary for scientists and educators to also consider the dynamic social and ecological contexts into which material hypotheses are thrown. This is a tall order.

As I have considered our dilemma, I can see three pathways to better engineering underway and a modern paradox that confounds them all:

Interdisciplinary Research: This pathway provides incentives for researchers from different academic communities (e.g. biology, law and city planning) to collaborate in the analysis of urban condition and to subsequently draft policies that can be empirically tested and revised ad infinitum. This is an approach already used by the U.S. National Science Foundation. Few institutions, however, have adopted interdisciplinarity as an academic model.

Creation of new hybrid educational systems: It has long been argued that significant new knowledge will not emerge in any of the traditional disciplines: e.g. chemistry, physics, or art. These disciplines have long ago become self-referential siloes of accepted epistemology. Rather, postmoderns argue for new areas of inquiry with names like: The College of Sustainability, The School for the Future of Innovation in Society, or the program for Anthropology of Complex Adaptive Systems Science. Fortunately, these three areas of study have already been established at Arizona State University, but more orthodox modern institutions lack the will to follow.

Community-based or participatory action learning: Community Action Learning (CAL) begins with the assumption that expert knowledge and local knowledge are not, as typically assumed, in conflict. Nor is one inherently superior to the other. Rather, each perspective provides what Donna Haraway has called "situated knowledge," and both are required to solve worldly problems. If experts command understanding of abstract concepts and global patterns, they lack the fine-grained knowledge of how "context-free" ideas align with "context-rich" conditions. And, 


\section{Civil Engineering Research Journal}

if locals command context-rich knowledge through everyday experience, they lack the knowledge of global patterns grasped by experts. The concept of community-based learning was developed by the philosopher John Dewey and his followers decades ago as an "unmodern" proposal but has never succeeded at a large scale.

The problem that faces these three pathways to better engineering design, and sustainable development, is that orthodox moderns find it paradoxical to accept social and ecological variables as equal to physical ones. It is certainly true that, in Francis Bacon's time, it was easier to calculate probability in the physical world than in ecological or social ones. That claim may still be true, but ecologists and social scientists have come a long

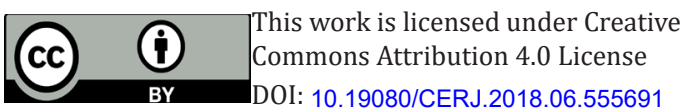

way in closing those knowledge gaps. So have citizen scientists. Today, the received opinion of Science seems contradictory to the common sense of locals. That means it is time to finish the modern project, which was just as much about achieving social justice as it was about achieving scientific certainty. The recent scholarship of complexity science has demonstrated that uncertainty may not be such a bad thing after-all. By expanding the boundaries of science to include ecological and social phenomena, we may have less certainty, but we gain the opportunity to hypothesize and test ecosociotechnical systems that transcend the premodern dualisms that have so diminished orthodox modern science and engineering.

\section{Your next submission with Juniper Publishers will reach you the below assets}

- Quality Editorial service

- Swift Peer Review

- Reprints availability

- E-prints Service

- Manuscript Podcast for convenient understanding

- Global attainment for your research

- Manuscript accessibility in different formats

( Pdf, E-pub, Full Text, Audio)

- Unceasing customer service

Track the below URL for one-step submission

https://juniperpublishers.com/online-submission.php 